\title{
Faktor-faktor yang Mempengaruhi Derajat Keparahan Erupsi Obat pada Anak
}

\section{Factors Affecting Drug Eruption Severity in Children}

\author{
Wisnu Barlianto \\ Laboratorium Ilmu Kesehatan Anak Fakultas Kedokteran Universitas Brawijaya Malang
}

\begin{abstract}
ABSTRAK
Erupsi obat merupakan respon normal terhadap kandungan atau metabolit pada obat yang muncul selama atau sesudah pemberian obat pada dosis normal. Tingkat keparahan erupsi obat di bagi menjadi dua yaitu non SIS/TEN (Stevens Johnson Syndrome/Toxic Epidermal Necrolysis) dan SJS/TEN. Penelitian ini dilakukan untuk mengindentifikasi faktor yang mempengaruhi derajat keparahan erupsi obat dengan menggunakan pendekatan cross-sectional. Data yang di ukur meliputi usia, jenis kelamin, riwayat atopi dan obat yang menyebabkan. Dari 34 responden yang mengalami erupsi obat 14 (41.2\%) termasuk tipe SJS/TEN dan 20 (58.8\%) termasuk tipe non SJS/TEN. Obat yang paling sering menyebabkan erupsi obat adalah paracetamol (41.2\%), amoxicillin (34.4\%), carbamazepin (8.8\%), cotrimoksazole (8.8\%), ceftriaxone, tetracycline dan aspirin masing-masing $2.9 \%$. Hasil uji chi-square menunjukkan tidak ada hubungan signifikan antara usia, jenis kelamin dan riwayat atopi dengan tingkat keparahan obat.
\end{abstract}

Kata Kunci : Anak, atopi, erupsi obat, jenis kelamin, malnutrisi, superoxide dismutase, tes morris watermaze, umur

\section{ABSTRACT}

Drug eruption is an abnormal response to one of the ingredients or metabolites during or after the use of drugs in normal dosage range. The degree of severity of drug eruption is divided into two groups namely non SJS/TEN (Stevens Johnson Syndrome/Toxic Epidermal Necrolysis) and SJS/TEN. This study is aimed to determine the factors that influence the degree of severity of drug eruption using cross sectional approach. Data measured including age, sex, history of atopy and drug causes in both groups. Of 34 people with drug eruption, 14 patients were SJS / TEN (41.2\%) and 20 patients were non SJS / TEN (58.8\%). The most frequent cause of eruption is paracetamol (41.2\%), followed by amoxicillin (32.4\%), carbamazepine (8.8\%), cotrimoksazole (8.8\%), ceftriaxone (2.9\%), tetracycline (2.9\%), and aspirin (2.9\%). Chi-square test show no significant association between age, sex, and history of atopy with the degree of drug eruptions

Keywords: Age, atopy, children, drug eruption, malnutrition, morris watermaze test, sex, superoxide dismutase

Jurnal Kedokteran Brawijaya, Vol. 26, No. 1, Februari 2010; Korespondensi: Wisnu Barlianto. Laboratorium IImu Kesehatan Anak Fakultas Kedokteran Universitas Brawijaya Malang, Jl. Veteran Malang Tel. (0341)569117Email:wisnu_barlian@yahoo.com 


\section{PENDAHULUAN}

Erupsi obat adalah respon abnormal seseorang terhadap bahan obat atau metabolitnya yang terjadi selama atau setelah pemakaian obat dalam rentang dosis normal (1). Erupsi obat pada anak lebih jarang terjadi dibandingkan dengan orang dewasa, akan tetapi sering menimbulkan masalah karena mirip dengan erupsi oleh karena virus (viral exanthema) dan gejala alergi oleh penyebab lain yang sering terjadi pada anak, misalnya alergi makanan $(1,2)$. Angka kejadian alergi obat di Klinik Alergi Imunologi Bagian Ilmu Kesehatan Anak FKUI/RSCM menurut Matondang dan Munasir (1990) adalah sebesar 0,01\% dengan manifestasi terbanyak pada kulit, sedangkan menurut Pardede (1993) sebesar 0,07\% dengan manifestasi terbanyak urtikaria (3). Insiden erupsi obat pada pasien anak yang menjalani rawat inap berkisar antara $0,59-4,1 \%$ pada beberapa penelitian sedangkan pada pasien anak rawat jalan antara 0,7-2,7\% (3). Jenis obat penyebab alergi sangat bervariasi dan berbeda menurut waktu, tempat, dan jenis penelitian yang dilaporkan. Pada umumnya laporan tentang obat tersering adalah golongan penisilin, sulfa, salisilat, paracetamol, dan anti konvulsan. Tetapi alergi obat dengan gejala klinis berat paling sering dihubungkan dengan penisilin dan sulfa (3).

Gejala klinis alergi obat sangat bervariasi dan tidak spesifik untuk obat tertentu. Satu macam obat dapat menimbulkan berbagai gejala, dan pada seseorang dapat berbeda dengan orang lain. Gejala klinis alergi obat dapat berupa gejala ringan sampai berat. Gejala yang berat dihubungkan dengan angka mortalitas yang tinggi (4). Erupsi kulit merupakan gejala klinis yang paling sering, dapat berupa pruritus, urtikaria, purpura, dermatitis kontak, eritema multiforme, fixed drug eruption (FDE) atau reaksi yang lebih berat berupa dermatitis eksfoliatif dan erupsi vesikobulosa seperti pada sindrom StevenJohnson (SJS) dan Eritema multiforme (EM) (3). Oleh karena itu, derajat keparahan erupsi obat dibagi menjadi dua yaitu kelompok non SJS/TEN dan kelompok SJS/TEN (Stevens Johnson Syndrome/Toxic Epidermal Necrolysis). Menurut penelitian Kidon dan See (2004), faktor risiko terjadinya risiko obat antara lain usia $>1$ tahun, jenis kelamin perempuan, adanya riwayat atopi pada pasien dan atau keluarga serta adanya penyakit defisiensi sistem imun yang mendasari (5). Sebaliknya penelitian Wahiduzzaman (2008) menyatakan jenis kelamin laki-laki lebih rentan terkena erupsi obat (6). Sebagian besar penelitian lebih banyak mengkaji faktor yang meningkatkan risiko terjadinya erupsi obat. Masih terbatas kajian tentang faktor yang mempengaruhi derajat keparahan erupsi obat.

Penelitian ini bertujuan untuk mengetahui faktor-faktor yang mempengaruhi derajat keparahan erupsi obat dengan menggunakan pendekatan cross sectional. Manfaat penelitian ini agar dokter lebih berhati-hati dalam meresepkan jenis-jenis obat tertentu terutama yang sering menimbulkan erupsi obat pada anak.

\section{METODE}

Penelitian dilakukan dengan metode observasional cross sectional pada penderita rawat inap di bangsal IImu Kesehatan Anak Rumah Sakit Saiful Anwar Malang. Penelitian melibatkan semua penderita dengan erupsi obat yang dirawat selama bulan Januari 2008 sampai Juli
2010. Data penelitian berasal dari data rekam medis pasien. Semua penderita yang dirawat dengan erupsi obat diikutkan dalam penelitian ini. Diagnosis erupsi obat secara klinis meliputi: urtikaria, angioedema, eritema multiforme (EM), fixed drug eruption (FDE), dermatitis eksfoliatif (DE), sindrom steven johnson (SJS), dan nekrolisis epidermal toksik (NET). Kriteria diagnosis berdasarkan rekam medik, yaitu penderita didiagnosa SJS dan atau NET jika terdapat kumpulan gejala klinis meliputi kelainan kulit, mukosa orifisium (oral,konjungtiva, dan anogenital) serta mata.

Lesi pada SJS meliputi < $10 \%$ luas permukaan tubuh,SJSNET $10-30 \%$, dan pada NET jika $>30 \%$ (4). Selanjutnya penderita dibagi menjadi dua kelompok yaitu kelompok erupsi obat berat (SJS/NET) dan tidak berat (non SJS/NET). Pengumpulan data meliputi usia, jenis kelamin dan riwayat atopi pada kedua kelompok. Usia pasien dibagi menjadi dua kelompok, yaitu $\leq 1$ tahun dan $>1$ tahun. Analisa statistik menggunakan Chi-square pada tingkat kepercayaan 95\% untuk mengetahui hubungan faktor tersebut dengan derajat keparahan erupsi obat.

\section{HASIL}

Selama penelitian didapatkan 34 orang pasien yang dirawat dengan diagnosa erupsi obat, 14 penderita SJS/NET (41,2\%) dan 20 penderita non SJS/NET (58,8\%). Penderita SJS sebanyak $13(38 \%)$, NET $1(2,9 \%)$, eritema multiforme 8 (24\%), angioedema $4(12 \%)$, urtikaria 3 $(8,9 \%)$, fixed drug eruption $3(8,9 \%)$, dan dermatitis eksfoliatif sebanyak 2 (6\%). Obat yang sering diresepkan atau menjadi penyebab erupsi obat antara lain, paracetamol $(14 / 41,2 \%)$, amoksisilin $(11 / 32,4 \%)$, carbamazepine $(3 / 8,9 \%)$, cotrimoksasol $(3 / 8,9 \%)$, seftriakson $(1 / 2,9 \%)$, tetrasiklin $(1 / 2,9 \%)$, dan aspirin $(1 / 2,9 \%)$. Uji Chi-square menunjukan faktor usia, jenis kelamin dan riwayat atopi tidak berhubungan dengan derajat erupsi obat (Tabel 1). Namun demikian, pemberian parasetamol meningkatkan risiko keparahan $(O R=2 ; p=0.43)$ erupsi obat, walaupun secara statistik tidak bermakna.

Tabel 1. Proporsi penderita berdasarkan usia, jenis kelamin dan riwayat atopi

\begin{tabular}{lccc}
\hline & SJS/NET (n=14) & Non SJS/NET (n=20) & P \\
\cline { 2 - 4 } $\begin{array}{lccc}\text { Usia } \\
\leq 1 \text { tahun, } \mathrm{n}(\%)\end{array}$ & $2(14,3)$ & $2(10)$ & 0,55 \\
$>1$ tahun, $\mathrm{n}(\%)$ & $12(85,7)$ & $18(90)$ & \\
$\begin{array}{l}\text { Jenis kelamin } \\
\text { Laki-laki, } \mathrm{n}(\%)\end{array}$ & $10(71,4)$ & $12(60)$ & 0,49 \\
$\begin{array}{l}\text { Perempuan, } \mathrm{n}(\%) \\
\text { Atopi }\end{array}$ & $4(28,6)$ & $8(40)$ & \\
$\begin{array}{l}\text { Riwayat atopi (+), } \mathrm{n}(\%) \\
\text { Riwayat atopi }(-), \mathrm{n}(\%)\end{array}$ & $7(50)$ & $14(70)$ & 0,24 \\
\end{tabular}

\section{DISKUSI}

Hasil penelitian ini menunjukan lebih dari $80 \%$ penderita SJS/NET berusia diatas 1 tahun. Reaksi terhadap obat jarang terjadi pada bayi ( $\leq 1$ tahun) dan usia tua, disebabkan oleh imaturitas ataupun involusi sistem imun (4). 
Penelitian Kidon dan See (2004) menyatakan bahwa ratarata usia rentan terjadi erupsi obat adalah 7.4 tahun (6). Namun demikian, tidak ada hubungan antara faktor usia dengan derajat keparahan erupsi obat.

Proporsi penderita SJS/NET pada perempuan lebih rendah daripada laki-laki walaupun secara statistik tidak bermakna. Wahiduzzaman dkk (2008) menyebutkan jenis kelamin laki-laki lebih rentan terjadi SIS/NET dengan penyebab belum diketahui secara pasti (5). Sebaliknya, beberapa penelitian lain menunjukan perempuan lebih rentan untuk mengalami alergi obat. Perempuan sangat rentan untuk mengalami gejala saluran pencernaan dan kulit akibat reaksi simpang obat. Hasil penelitian Domeq, dkk (1980) memperkirakan angka insiden erupsi obat pada pria $83 \%$ dan pada perempuan $93 \%(3,7)$. Perempuan memiliki risiko 35 kali terjadi erupsi obat yang berat pada kulit $(8,9,10)$.

Hasil penelitian ini menunjukkan bahwa riwayat atopi tidak berhubungan dengan terjadinya erupsi obat yang berat (SJS/NET). Hal ini disebabkan oleh karena erupsi obat tidak hanya disebabkan oleh reaksi hipersensitifitas tipe 1 tetapi juga bisa oleh karena reaksi hipersensitifitas tipe 2 dan 4. Studi lain menunjukan anak dengan riwayat alergi obat pada orang tuanya mempunyai risiko terjadinya alergi obat sebanyak $25 \%$ dibandingkan dengan anak-anak yang orang tuanya tidak mempunyai riwayat alergi obat (3). Latar belakang atopi meningkatkan risiko reaksi hipersensitifitas tipe cepat terhadap obat menjadi lebih berat atau parah. Adanya predisposisi atopi tidak meningkatkan kejadian erupsi obat tetapi berhubungan dengan erupsi obat yang berat (11-13).

Jenis obat penyebab alergi sangat bervariasi dan berbeda menurut waktu, tempat dan jenis penelitian yang dilaporkan. Tingginya angka kejadian alergi obat berhubungan erat dengan kekerapan pemakaian obat tersebut (4). Hasil penelitian ini menunjukkan bahwa parasetamol dan amoksisilin sebagai penyebab terbanyak erupsi obat pada anak. Keduanya merupakan obat yang sering digunakan secara bebas di Indonesia. Pola ini tidak berbeda dengan studi yang melaporkan obat penyebab alergi tersering seperti golongan penisilin, sulfa, salisilat,

\section{DAFTAR PUSTAKA}

1. Khoo BP and Giam YC. Drug Eruption in Children: $A$ Review of 111 Cases Seen in a Tertiary Skin Referral Centre. Singapore Medical Journal. 2000; 4(11): 525529.

2. Ghazi SBMS, Dibaee M, Salamati $P$, Manesh $A A R$, and Akhlaghi H. Adverse Drug Reactions, As a Cause for Admission to a Children's Hospital. Iranian Journal of Pediatric. 2007: 17(1): 11-14.

3. Akib AP, Takumansang DS, Sumadiono, et al. Alergi Obat. Di dalam: Buku Ajar Alergi-Imunologi Anak edisi 2. Jakarta: Balai Penerbit IDAl; 2008: hal. 294-306.

4. Fromowitz JS, Ramos-Caro FA, and Flowers FP. Practical Guidelines for the Management of Toxic Epidermal Necrolysis and Steven_Johnson Syndrome. International Journal of Dermatology. 2007; 46(10): 1092-1094.

5. Wahiduzzaman $\mathrm{M}$ and Pubalan M. Steven_Johnson syndrome (SJS) and Toxic Epidermal Necrolysis (TEN) in Sarawak: A Four Years Review. Egyptian Dermatology dan paracetamol. Obat lain yang sering dilaporkan adalah asam mefenamat, luminal, fenitoin, antikonvulsan (6) Penelitian Jha, dkk tahun 2007 menyatakan bahwa antibiotik amoksisilin merupakan penyebab paling banyak reaksi simpang obat pada berbagai rumah sakit di Kathmandu,India (14). Demikian juga hasil penelitian case control oleh Kidon dan See (2004) menunjukkan bahwa 2/3 kejadian erupsi obat akibat antibiotik disebabkan oleh golongan betalaktam (6) Golongan penisilin merupakan obat dengan berat molekul kecil yang bersifat imunogenik jika bergabung dengan protein karier seperti albumin oleh karena dapat membentuk hapten. Penggunaan berulang juga meningkatkan risiko reaksi imun yang terjadi. Alergi obat golongan beta laktam sering menimbulkan reaksi anafilaksis dan kematian. Obat golongan penisilin menimbulkan reaksi hipersensitifitas tipe I (diperantarai oleh IgE) sehingga bisa menimbulkan gejala berupa urtikaria, edema laring, wheezing dan kolaps kardiorespiratorius (15). Penelitian ini menunjukan juga bahwa parasetamol merupakan penyebab terjadinya erupsi obat yang berat. Hal ini berbeda dengan penelitian sebelumnya yang menyatakan penisilin dan sulfa sebagai penyebab tersering erupsi obat berat (15).

Keterbatasan penelitian ini adalah tidak adanya pemeriksaan penunjang yang baku untuk menegakan diagnosis alergi obat, sehingga diagnosis hanya ditegakkan secara klinis. Manifestasi klinis yang berat bisa merupakan bagian dari perjalanan penyakit yang mendasari. Selain itu, sebagian kasus eritema multiforme disebabkan oleh infeksi dan hanya $10 \%$ yang kemungkinan berhubungan dengan penggunaan obat.

Pada penelitian ini erupsi obat yang banyak ditemukan adalah tipe SJS dan NET, sedangkan eritema multiforme, angioedema, urtikaria, fixed drug eruption, dan dermatitis eksfoliatif lebih sedikit. Obat yang menjadi penyebab erupsi obat terbanyak adalah paracetamol dan amoksisilin. Faktor usia, jenis kelamin dan riwayat atopi tidak mempengaruhi derajat keparahan erupsi obat. Diperlukan penelitian lebih lanjut dengan sampel yang lebih besar, multicenter, dan pemeriksaan penunjang yang lebih lengkap untuk menegakan diagnosis erupsi obat.

Online Journal. 2008: 4(1): 1-10.

6. Kidon $\mathrm{Ml}$ and See Y. Adverse Drug Reactions in Singaporean Children. Singapore Medical Journal.

2004: 45(12): 574-577.

7. Impicciatore $\mathrm{P}$, Choonara I, Clarkson A, Provasi D, Pandolfini $\mathrm{C}$, and Bonati M. Incidence of Adverse Drug Reactions in Paediatric In/out-patients:a Systematic Review and Meta-analysis of Prospective Studies. British Journal of Clinical Pharmacology. 2001: 52: 7783.

8. Vervloet $D$ and Durham S. Adverse Reactions to Drugs. British Medical Journal. 1998; 316: 1511.

9. Lang DM, Alpern MB, and Visintainer PF. Gender Siskfor Anaphylactoid Reaction to Radiographic Contrast Media. Journal of Allergy and Clinical Immunology. 1995; 95(4): 813-817.

10. Co Minh HB, Bousquet PJ, Fontaine $C$, Kvedariene $V$, and Demoly P. Systemic Reactions During Skin Tests with 
Beta - lactams: A Risk Factor Analysis. Journal of Allergy and Clinical Immunology. 2006; 117(2):466468.

11. Friedman PS, Lee MS, and Barneston RS. Mechanisms in Caneous Drug Hypersensitivity Reactions. Clinical \& Experimental Allergy. 2003; 33: 861-872.

12. Ponvert $\mathrm{C}$, Scheinmann $\mathrm{P}$, Perrin $\mathrm{Y}$, et al. Allergy to Beta-lactam Antibiotics in Children. Pediatrics. 2011; 22(4): 411-418.

13. Demoly P and Gomes ER. Drug Hypersensitivities:
Definition, Epidemiology and Risk Factors. European Annals of Allergy and Clinical Immunol. 2005:37:202206.

14. Hershkovich J, Broides A, Kirjner L, Smith H, and Gorodischer R. Beta Lactam Allergy and Resensitization in Children with Suspected Beta Lactam Allergy. Clinical Experimental \& Allergy. 2009; 39: 726-730.

15. Bousquet PJ, Pipet A, Bousquet-Rouanet, and Demoly P. Oralchallenges are Needed in The Diagnosis of BetaLactam Hyper-Sensitivity. Clinical Experimental \& Allergy. 2008; 38(1): 185-190. 